\title{
Antimicrobial efficacy of $2.5 \%$ sodium hypochlorite, $2 \%$ chlorhexidine, and ozonated water as irrigants in mesiobuccal root canals with severe curvature of mandibular molars
}

\author{
Sergio Luiz Pinheiro ${ }^{1}$, Caio Cesar da Silva ${ }^{1}$, Lucas Augusto da Silva ${ }^{1}$, Marina P. Cicotti ${ }^{1}$, \\ Carlos Eduardo da Silveira Bueno ${ }^{1}$, Carlos Eduardo Fontana ${ }^{1}$, Letícia R. Pagrion ${ }^{1}$, \\ Natália P. Dalmora ${ }^{1}$, Thaís T. Daque ${ }^{1}$, Francisco UF de Campos $^{2}$
}

Correspondence: Dr. Sergio Luiz Pinheiro

Email: slpinho@puc-campinas.edu.br
'Department of Endodontics, Pontifícia Universidade Católica de Campinas, Campinas, SP, Brazil, 'Department of Endodontics, São Leopoldo Mandic, Campinas, SP, Brazil

\section{ABSTRACT}

Objective: The aim of this study is to evaluate the antimicrobial efficacy of $2.5 \%$ sodium hypochlorite, $2 \%$ chlorhexidine, and ozonated water on biofilms of Enterococcus faecalis, Streptococcus mutans, and Candida albicans in mesiobuccal root canals with severe curvature of mandibular molars. Materials and Methods: This was an experimental ex vivo study in microbiologic laboratory. Sixty mesiobuccal root canals with severe curvature of mandibular molars were contaminated with standard strains of E. faecalis, S. mutans, and C. albicans. The specimens were randomly divided into four groups $(n=15)$ according to irrigating solution: $\mathrm{SH}$ : $2.5 \%$ sodium hypochlorite; $\mathrm{CH}: 2 \%$ chlorhexidine; $\mathrm{O}_{3}$ : ozonated water; and control: double-distilled water. The mesiobuccal root canals of all groups were instrumented with the WaveOne Gold Primary reciprocating system. Three cycles of instrumentation with three short in-and-out brushing motions were performed: (1) in the coronal third, (2) in the middle third, and (3) in the apical third of the canal. A ProGlider file was used before the first cycle. Statistical Analysis: Statistical analysis was performed using one-way analysis of variance followed by Tukey's multiple comparison test. Samples were collected for viable bacterial counts before and after instrumentation. Results: All groups showed significant biofilm reduction after irrigation $(P<0.01)$. After instrumentation, sodium hypochlorite $(98.07 \%)$, chlorhexidine $(98.31 \%)$, and ozonated water $(98.02 \%)$ produced a significantly reduction in bacterial counts compared with double-distilled water (control, 72.98\%) $(P<0.01)$. Conclusion: All irrigants tested in this study showed similar antimicrobial activity. Thus, ozonated water may be an option for microbial reduction in the root canal system.

Key words: Endodontic treatment, irrigation, reciprocating system

\section{INTRODUCTION}

Disinfection of the root canal system is essential for successful endodontic treatment. ${ }^{[1]}$ Root canals are usually infected by multiple bacteria. ${ }^{[2-7]}$

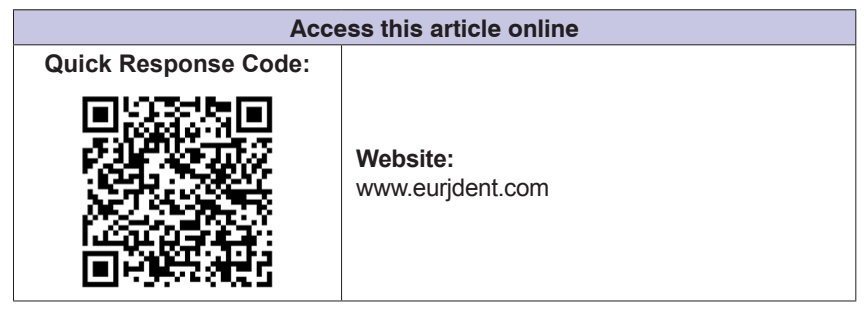

This is an open access article distributed under the terms of the Creative Commons Attribution-NonCommercial-ShareAlike 3.0 License, which allows others to remix, tweak, and build upon the work non-commercially, as long as the author is credited and the new creations are licensed under the identical terms.

For reprints contact: reprints@medknow.com

How to cite this article: Pinheiro SL, da Silva CC, da Silva LA, Cicotti MP, Bueno CE, Fontana CE, et al. Antimicrobial efficacy of $2.5 \%$ sodium hypochlorite, $2 \%$ chlorhexidine, and ozonated water as irrigants in mesiobuccal root canals with severe curvature of mandibular molars. Eur J Dent 2018;12:94-9.

DOI: 10.4103/ejd.ejd_324_17 
In general, $2.5 \%$ sodium hypochlorite and 2\% chlorhexidine are used as irrigating solutions in endodontics. ${ }^{[8]}$ Sodium hypochlorite has been used as an irrigant because of its broad antimicrobial spectrum and ability to dissolve necrotic tissue remnants ${ }^{[9]}$ while $2 \%$ chlorhexidine has been used as an irrigant due to its broad antimicrobial activity, substantivity, and low cytotoxicity. ${ }^{[10]}$ An alternative that is currently being considered for disinfection of the root canal system is ozone therapy. Ozone is applied to oral tissues in the forms of ozonated water, ozonated oil, and oxygen/ozone gas either alone or in combination to treat dental disease. Ozone has a high oxidation potential, being 1.5 times more effective than chloride as an antimicrobial agent against several microorganisms, and it can also stimulate blood flow and immune response. ${ }^{[1]}$ An increasing number of irrigants have been proposed in an attempt to achieve optimal irrigation. However, none of the available irrigants showed all the necessary requirements. ${ }^{[12]}$

No published studies have assessed microbial load reduction in the root canal system with a combination of reciprocating instrumentation and irrigation with ozonated water. Reciprocating instrumentation shapes the root canal system rapidly, thus enabling high-flow, large-volume irrigation, while the biocompatibility and properties of ozonated water make it an interesting alternative irrigant. Within this context, the present study sought to evaluate the antimicrobial efficacy of $2.5 \%$ sodium hypochlorite, $2 \%$ chlorhexidine, and ozonated water on biofilms of Enterococcus faecalis, Streptococcus mutans, and Candida albicans in mesiobuccal root canals of mandibular molars. The null hypothesis was that equivalent reductions in biofilm formation would be achieved with the use of $2.5 \%$ sodium hypochlorite, $2 \%$ chlorhexidine, and ozonated water as irrigants.

\section{MATERIALS AND METHODS}

\section{Sample selection}

Sixty permanent mandibular molars were selected among teeth donated by patients at dental clinic. Written informed consent was obtained from all patients before donation. The study was approved by Research Ethics Committee (protocol number: 1.841.252).

The sample size was calculated based on a pilot data set using analysis of variance (ANOVA) with statistical power of 0.80 and alpha of 0.05 . A sample size of 15 specimens per group was required.
Theinclusion criteria were as follows: ${ }^{[13,14]}$ completeroot formation, no previous of endodontic treatment, no pathological external and/ or internal root resorption, no root cracks or fractures, root length $\geq 15 \mathrm{~mm}$, distinct foramina for the mesiobuccal and mesiolingual canals, root curvature $25^{\circ}-40^{\circ}$ (severe) (Schneider 1971), and anatomical canal diameter compatible with a size \#15 K-file.

\section{Tooth preparation}

The teeth were radiographed in the buccolingual direction, and the degree of curvature of the mesiobuccal root canal was determined. ${ }^{[15]}$ The crowns were removed with double-sided diamond discs (Microdont, São Paulo, SP, Brazil), and root length was standardized to $15 \mathrm{~mm}$. The mesial root length was determined with a digital caliper (Starrett, Itu, $\mathrm{SP}$, Brazil). The orifice of the mesiolingual and distal canals was sealed with light-curing resin (Z250 XT; $3 \mathrm{M}$, Deutschland, Germany). ${ }^{[14]}$

The working length was determined visually by inserting a size \#15 (Dentsply Maillefer, Ballaigues, Switzerland) into the root canal until its tip was visible at the apical foramen under operating microscope visualization (8X). The file was then withdrawn $1 \mathrm{~mm}$ to determine the working length. Before contamination, the canals were manually instrumented with size \#10 and \#15 K-files (Dentsply Maillefer, Ballaigues, Switzerland) until reaching the working length and irrigated with $5 \mathrm{~mL}$ of distilled water (Dinâmica, Campinas, SP, Brazil). The apical foramen and the external surfaces of all roots were sealed. ${ }^{[16]}$ The specimens were sterilized in an autoclave (Sercon, Mogi das Cruzes, SP, Brazil) at $121^{\circ} \mathrm{C}$ for $15 \mathrm{~min}$.

The root canals were contaminated with standard strains of E. faecalis (ATCC 29212; LabCenter, Campinas, SP, Brazil), S. mutans (25175; LabCenter, Campinas, SP, Brazil), and C. albicans (10231; LabCenter, Campinas, SP, Brazil)). The bacterial suspension was prepared in a tube containing $10 \mathrm{~mL}$ of sterile saline (Dinâmica, Campinas, SP, Brazil), matched to a 10 McFarland standard. ${ }^{[14,17]}$

A $20-\mu \mathrm{L}$ aliquot of the final suspension was injected into each root canal using a 0.3-cc insulin syringe (Ultrafine BD, São Paulo, SP, Brazil). Specimens were stored in 24-well cell culture plates (CoStar, New York, NY, USA) in an incubator (Fanem Ltda, São Paulo, $\mathrm{SP}$, Brazil) at $37^{\circ} \mathrm{C}$ in a $5 \% \mathrm{CO}_{2}$ atmosphere for 21 days. ${ }^{[14,16-18]}$ 
The viability and purity of the microorganisms within the canals were checked weekly by random sampling of two specimens using sterile paper points. ${ }^{[14,16,19]}$

Bacterial samples were collected using sterile paper points (Dentsply Maillefer, Ballaigues, Switzerland) compatible with the anatomical diameter of the root canal before and after instrumentation. ${ }^{[14,19]}$ The paper point was inserted into the canal for $30 \mathrm{~s}$ and immediately placed in a test tube containing $5 \mathrm{~mL}$ of BHI broth (Acumedia Manufacturers, Lansing, MI, USA).

\section{Canal instrumentation}

Instrumentation was performed using the WaveOne Gold (WOG) single-file reciprocating system (Dentsply Maillefer, Ballaigues, Switzerland), powered by an X-Smart Plus electric motor (Dentsply Maillefer, Ballaigues, Switzerland) set to operate in the WaveOne mode, with a slight pressure in the apical direction of up to 3-4 $\mathrm{mm}$.

Instrumentation was performed according to the manufacturer's instructions. A size \#15 (Dentsply Maillefer, Ballaigues, Switzerland) was used to confirm the path of the canal to the foramen. The glide path was expanded by at least $0.16 \mathrm{~mm}$ using a ProGlider file (Dentsply Maillefer, Ballaigues, Switzerland) until the working length was reached. Before the first cycle of WOG file, a ProGlider file (Dentsply Maillefer, Ballaigues, Switzerland) was applied in one in-and-out brushing motion at a speed of $300 \mathrm{rpm}$ with light apical pressure, set at $2 \mathrm{Ncm}$ for torque control. The Primary WOG 25/.07 file was the file that best fitted to the canal and was used to the full working length. The Primary 25/.07 and ProGlider files were single use.

Three cycles of instrumentation were performed. Each cycle consisted of three short in-and-out brushing motions. ${ }^{[17]}$

The canals were irrigated using a 5-mL plastic syringe (Ultradent Products Inc., South Jordan, UT, USA) with a $0.55 \times 20 \mathrm{~mm}$ hypodermic needle (24G; Ultrafine BD, São Paulo, SP, Brazil), inserted up to the middle third of the canal $(10 \mathrm{~mm})$. All canals were instrumented by the same operator.

The specimens were randomly divided ( $w w w$. random.org.br) into four groups $(n=15)$ according to irrigating solution: $\mathrm{SH}: 2.5 \%$ sodium hypochlorite (compounded - Farmácia Art Med, Jundiaí, SP, Brazil); CH: $2 \%$ chlorhexidine solution (compounded - Farmácia Art Med, Jundiaí, SP, Brazil); $\mathrm{O}_{3}$ : ozonated water $(40 \mu \mathrm{g} / \mathrm{mL})$; and control: double-distilled water.

In all groups, before instrumentation, samples were collected for viable bacterial counts. After use of the ProGlider file (Dentsply Maillefer, Ballaigues, Switzerland) and during instrumentation (each cycle), canals were irrigated with the solutions corresponding to groups $\mathrm{SH}, \mathrm{CH}, \mathrm{O}_{3^{\prime}}$ and control, for $3 \mathrm{~min}$, using $5 \mathrm{~mL}$ (10) of the irrigating solution, for a total of $20 \mathrm{~mL}$ irrigant. After this protocol, a new sample collection was performed for viable bacterial counts.

\section{Preparation of ozonated water}

An ozone generator was used (Philozon, Camboriu, SC, Brazil). Sterile double-distilled water was cooled at $14^{\circ} \mathrm{C}$ and kept under refrigeration until use. The ozone gas was adjusted in the generator to the concentration required for this experimental model $(40 \mu \mathrm{g} / \mathrm{mL}) .{ }^{[20]}$

\section{Specimen culture}

The specimens were diluted, seeded, and cultured. Total viable bacterial count was determined using a colony counter. Counts were given as colony-forming units (CFU).

\section{Statistical analysis}

Antimicrobial efficacy was evaluated as bacterial growth (in CFU $/ \mathrm{mL}$ ) and percentage biofilm reduction. Percentage reduction of biofilm was calculated using the following formula:

$$
\begin{gathered}
\mathrm{BCB}-100 \% \\
\mathrm{X} \\
(\mathrm{BCB}-\mathrm{BCA})-\mathrm{X} \%
\end{gathered}
$$

$\mathrm{BCB}$, biofilm count before instrumentation; $\mathrm{BCA}$, biofilm count after instrumentation.

Results were analyzed using Biostat 4.0 (Sociedade Civil Mamirauá, Belém, Pará, Brasil). All data obtained in CFU/mL were $\log _{10}$ transformed. The $\log _{10}$-transformed and percentage biofilm reduction data were tested for normality using the Shapiro-Wilk test. All data were found to be normally distributed and therefore analyzed using one-way ANOVA followed by Tukey's multiple comparison test at the $1 \%$ significance level.

\section{RESULTS}

Bacterial counts obtained before and after root canal instrumentation were compared and all groups 


\begin{tabular}{|c|c|c|c|c|c|c|c|c|}
\hline & \multicolumn{2}{|c|}{$2.5 \% \mathrm{SH}$} & \multicolumn{2}{|c|}{$2 \% \mathrm{CH}$} & \multicolumn{2}{|c|}{$\mathrm{O}_{3}$} & \multicolumn{2}{|c|}{ Control } \\
\hline & Before & After & Before & After & Before & After & Before & After \\
\hline Mean (SD) & $4.60(0.09)^{\mathrm{A}, \mathrm{a}}$ & $2.88(0.11)^{\mathrm{B}, \mathrm{a}}$ & $4.57(0.13)^{\mathrm{A}, \mathrm{a}}$ & $2.77(0.14)^{\mathrm{B}, \mathrm{a}}$ & $4.56(0.10)^{\mathrm{A}, \mathrm{a}}$ & $2.79(0.11)^{\mathrm{B}, \mathrm{a}}$ & $4.59(0.07)^{a}$ & $4.02(0.08)^{b}$ \\
\hline$P$ & \multicolumn{8}{|c|}{ ANOVA (with Tukey test): $<0.0001$} \\
\hline
\end{tabular}

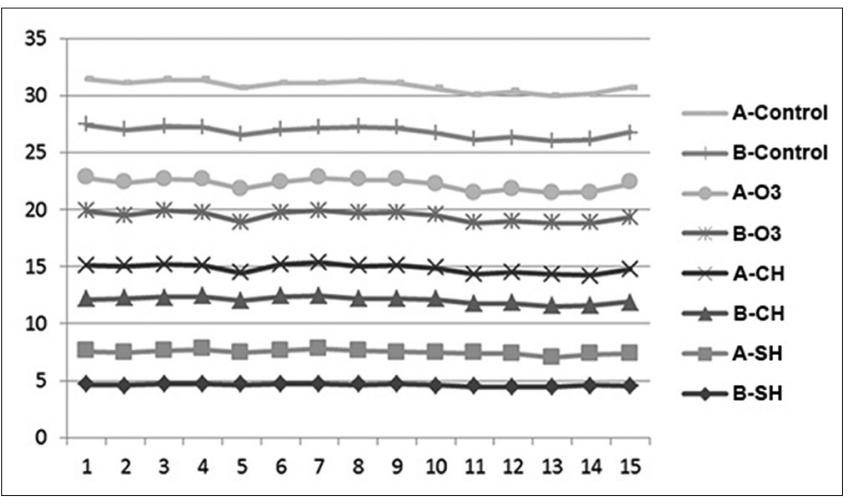

Figure 1: Bacterial counts $\left(\log _{10} \mathrm{CFU} / \mathrm{mL}\right)$ before $(\mathrm{B})$ and after $(\mathrm{A})$ the use of irrigating solutions

showed significant biofilm reduction after irrigation $(P<0.01)$ [Table 1 and Figure 1]. Biofilm reduction after instrumentation was compared between the groups, and $2.5 \%$ sodium hypochlorite $\left(2.88 \log _{10} \mathrm{CFU} / \mathrm{mL}\right.$, $98.07 \%), 2 \%$ chlorhexidine ( $\left.2.77 \log _{10} \mathrm{CFU} / \mathrm{mL}, 98.31 \%\right)$, and ozonated water $\left(2.79 \log _{10} \mathrm{CFU} / \mathrm{mL}, 98.02 \%\right)$ produced a significantly greater reduction in bacterial counts compared with distilled water (control) $\left(4.02 \log _{10} \mathrm{CFU} / \mathrm{mL}, 72.98 \%\right)(P<0.01)$ There was no significant difference in reduction of bacterial load between the test groups [Tables 1 and 2].

\section{DISCUSSION}

The experimental procedure of biofilm analysis of this study was based on the studies of Machado et al., ,17] Cord et al., ${ }^{[14]}$ Ghinzelli et al., ${ }^{[21]}$ and Pinheiro et al. ${ }^{[22]}$ The culture method to evaluate antibacterial activity was based on the study of Alves et al., ${ }^{[23]}$ who indicated that the culture method can be used effectively in ex vivo studies to test the antibacterial efficacy of treatment protocols and it is equivalent to polymerase chain reaction. Serial dilutions and sowing in BHI agar for counting CFU were performed according to Le Goff et al. ${ }^{[2]}$

The microbial reduction produced by $2.5 \%$ sodium hypochlorite $(98.07 \%$ ) may be explained based on the observations of Rutala and Weber, ${ }^{[25-27]}$ who suggested

\begin{tabular}{|c|c|c|c|c|}
\hline & $2.5 \% \mathrm{SH}$ & $2 \% \mathrm{CH}$ & $\mathrm{O}_{3}$ & Control \\
\hline Mean (SD) & $98.07(0.44)^{\mathrm{A}}$ & $98.31(0.48)^{A}$ & $98.02(0.60)^{\mathrm{A}}$ & $72.98(3.02)^{\mathrm{B}}$ \\
\hline$P$ & & JOVA (with Tuk & ey test): $<0.00$ & \\
\hline \multicolumn{5}{|c|}{$\begin{array}{l}\text { Different uppercase letters: } P<0.01 \text {. SH: } 2.5 \% \text { sodium } \\
\text { hypochlorite, } \mathrm{CH}: 2 \% \text { chlorhexidine, } \mathrm{O}_{3} \text { : Ozonated water, } \\
\text { ANOVA: Analysis of variance, SD: Standard deviation }\end{array}$} \\
\hline
\end{tabular}

that, when combined with water, sodium hypochlorite produces hypochlorous acid, which contains active chlorine. Chlorine exerts its bactericidal action through the irreversible oxidation of sulfhydryl groups of essential bacterial enzymes, disrupting the metabolic function of bacterial cellss ${ }^{[8]}$ Sodium hypochlorite may also have a deleterious effect on bacterial DNA, which involves the formation of chlorinated derivatives of nucleotide bases. In addition, there are reports that sodium hypochlorite may induce bacterial membrane disruption. ${ }^{[28]}$ According to Estrela et al., ${ }^{[29]}$ the tissue dissolution capacity of sodium hypochlorite is based on the reaction with fatty acids and lipids, which are transformed into soap and alcohol. Hypochlorous acid and hypochlorite ions lead to amino acid degradation and hydrolysis.

Chlorhexidine reduced bacterial counts by $98.31 \%$ after instrumentation probably due to its ability to adsorb to dentin, acting on bacterial cell walls and cytoplasmic membrane, resulting in the loss of osmotic balance and leakage of intracellular material. ${ }^{[30]}$ Its antimicrobial activity has residual effects ranging from 7 days $^{[31]}$ to 12 weeks. Chlorhexidine substantivity is facilitated by its viscosity, which keeps the solution in contact with the canal walls and dentinal tubules. ${ }^{[32]}$ According to Estrela et al., ${ }^{[29]}$ the antimicrobial activity of chlorhexidine may be explained by the interaction between its cationic nature and the anionic compound on the bacterial surface (phosphatase groups of teichoic acids in Gram-positive bacteria and lipopolysaccharides in Gram-negative bacteria). According to Gomes 
et al., ${ }^{[32]}$ low concentrations of chlorhexidine allow low-molecular-weight substances to be released, resulting in bacteriostatic effects. At high concentrations, it has bactericidal effects due to precipitation and/or coagulation of the cytoplasm.

The microbial reduction promoted by ozonated water $(98.02 \%)$ is in agreement with the study of Nogales et al., ${ }^{[20]}$ who stated that ozone was a promising agent for endodontic treatment. Ozone's oxidizing power is exerted specifically on polyunsaturated fatty acids of the bacterial membrane, increasing oxygen delivery to tissues and modulating the immune system, thereby improving and accelerating tissue repair. According to Goztas et al., ${ }^{[33]}$ the advantages of ozone in the aqueous phase include lack of mutagenicity, rapid microbicidal effects, and ease of handling. The authors also reported that ozonated water shows no cytotoxicity and is highly biocompatible compared with other antimicrobial agents. Ozone may have other clinical applications in addition to root canal irrigation, unlike hypochlorite and chlorhexidine, which have no other therapeutic uses in dentistry; this would justify the financial investment in ozonation equipment.

The control group also showed a significant microbial reduction after instrumentation $(72.98 \%)$. This result was probably due to instrumentation using the WOG reciprocating system. The design and gold wire alloy in the system make the file more flexible and more efficient in terms of cutting efficiency compared with other nickel-titanium systems. These features increase the capacity to auger debris out of the coronal third of the canal. ${ }^{[34]}$

\section{CONCLUSION}

We believe that the properties of ozone, in aqueous phase, render it an important disinfectant in endodontic treatment. In this respect, in addition to its oxidative potential to induce the destruction of bacterial cell walls and cytoplasmic membrane, ozone acts on glycoproteins, glycolipids, and amino acids, inhibiting the enzymatic control system of the cell. This results in increased membrane permeability, which allows ozone molecules to easily penetrate the cell and induce microbial lysis. Ozonated water has been demonstrated in several studies as a solution of good applicability with quite promising results, and the present findings confirm what has been reported in the literature. Moreover, the ozone generator is extremely cost-effective and easy to operate and may be a valuable tool for clinical use by endodontists.
Financial support and sponsorship

Nil.

\section{Conflicts of interest}

There are no conflicts of interest.

\section{REFERENCES}

1. Paqué F, Ganahl D, Peters OA. Effects of root canal preparation on apical geometry assessed by micro-computed tomography. J Endod 2009;35:1056-9.

2. Ghivari SB, Kubasad GC, Deshpande P. Comparative evaluation of apical extrusion of bacteria using hand and rotary systems: An in vitro study. J Conserv Dent 2012;15:32-5.

3. Machado ME, Sapia LA, Cai S, Martins GH, Nabeshima CK Comparison of two rotary systems in root canal preparation regarding disinfection. J Endod 2010;36:1238-40.

4. Gomes BP, Pinheiro ET, Gadê-Neto CR, Sousa EL, Ferraz CC, Zaia AA, et al. Microbiological examination of infected dental root canals. Oral Microbiol Immunol 2004;19:71-6.

5. Rôças IN, Siqueira JF Jr., Debelian GJ. Analysis of symptomatic and asymptomatic primary root canal infections in adult norwegian patients. J Endod 2011;37:1206-12.

6. Mohammadi Z, Asgary S. A comparative study of antifungal activity of endodontic irrigants. Iran Endod J 2015;10:144-7.

7. Kumar J, Sharma R, Sharma M, Prabhavathi V, Paul J, Chowdary CD, et al. Presence of Candida albicans in root canals of teeth with apical periodontitis and evaluation of their possible role in failure of endodontic treatment. J Int Oral Health 2015;7:42-5.

8. Estrela C, Estrela CR, Decurcio DA, Hollanda AC, Silva JA. Antimicrobial efficacy of ozonated water, gaseous ozone, sodium hypochlorite and chlorhexidine in infected human root canals. Int Endod J 2007;40:85-93.

9. Zehnder M. Root canal irrigants. J Endod 2006;32:389-98.

10. Gomes BP, Vianna ME, Zaia AA, Almeida JF, Souza-Filho FJ, Ferraz CC, et al. Chlorhexidine in endodontics. Braz Dent J 2013;24:89-102.

11. Mohammadi Z, Shalavi S, Soltani MK, Asgary S. A review of the properties and applications of ozone in endodontics: An update. Iran Endod J 2013;8:40-3.

12. Haapasalo M, Shen $Y$, Qian W, Gao Y. Irrigation in endodontics. Dent Clin North Am 2010;54:291-312.

13. Alkahtani A, Al Khudhairi TD, Anil S. A comparative study of the debridement efficacy and apical extrusion of dynamic and passive root canal irrigation systems. BMC Oral Health 2014;14:12.

14. Cord CB, Velasco RV, Ribeiro Melo Lima LF, Rocha DG, da Silveira Bueno CE, Pinheiro SL, et al. Effective analysis of the use of peracetic acid after instrumentation of root canals contaminated with Enterococcus faecalis. J Endod 2014;40:1145-8.

15. Schneider SW. A comparison of canal preparations in straight and curved root canals. Oral Surg Oral Med Oral Pathol 1971;32:271-5.

16. Nóbrega LM, Gadê-Neto CR, Dametto FR, Sarmento CF, de Carvalho RA. Ultrasonic irrigation in the removal of smear layer and Enterococcus faecalis from root canals. Braz J Oral Sci 2011;10:221-5.

17. Machado ME, Nabeshima CK, Leonardo MF, Reis FA, Britto ML, Cai $S$, et al. Influence of reciprocating single-file and rotary instrumentation on bacterial reduction on infected root canals. Int Endod J 2013;46:1083-7.

18. Matos Neto M, Santos SS, Leão MV, Habitante SM, Rodrigues JR, Jorge $\mathrm{AO}$, et al. Effectiveness of three instrumentation systems to remove Enterococcus faecalis from root canals. Int Endod J 2012;45:435-8.

19. Atila-Pektaş B, Yurdakul P, Gülmez D, Görduysus O. Antimicrobial effects of root canal medicaments against Enterococcus faecalis and Streptococcus mutans. Int Endod J 2013;46:413-8.

20. Nogales CG, Ferreira MB, Montemor AF, Rodrigues MF, Lage-Marques JL, Antoniazzi JH, et al. Ozone therapy as an adjuvant for endondontic protocols: Microbiological - Ex vivo study and citotoxicity analyses. J Appl Oral Sci 2016;24:607-13.

21. Ghinzelli GC, Souza MA, Cecchin D, Farina AP, de Figueiredo JA. Influence of ultrasonic activation on photodynamic therapy over root canal system infected with Enterococcus faecalis - An in vitro study. 
Photodiagnosis Photodyn Ther 2014;11:472-8.

22. Pinheiro SL, Azenha GR, Democh YM, Nunes DC, Provasi S, Fontanetti GM, et al. Antimicrobial activity of photodynamic therapy against Enterococcus faecalis before and after reciprocating instrumentation in permanent molars. Photomed Laser Surg 2016;34:646-51.

23. Alves FR, Rôças IN, Almeida BM, Neves MA, Zoffoli J, Siqueira JF Jr., et al. Quantitative molecular and culture analyses of bacterial elimination in oval-shaped root canals by a single-file instrumentation technique. Int Endod J 2012;45:871-7.

24. Le Goff A, Bunetel L, Mouton C, Bonnaure-Mallet M. Evaluation of root canal bacteria and their antimicrobial susceptibility in teeth with necrotic pulp. Oral Microbiol Immunol 1997;12:318-22.

25. Rutala WA, Weber DJ. Uses of inorganic hypochlorite (bleach) in health-care facilities. Clin Microbiol Rev 1997;10:597-610.

26. Vajrabhaya LO, Sangalungkarn V, Srisatjaluk R, Korsuwannawong S, Phruksaniyom C. Hypochlorite solution for root canal irrigation that lacks a chlorinated odor. Eur J Dent 2017;11:221-5.

27. Podar R, Kulkarni GP, Dadu SS, Singh S, Singh SH. In vivo antimicrobial efficacy of $6 \%$ morinda citrifolia, azadirachta indica, and 3\% sodium hypochlorite as root canal irrigants. Eur J Dent 2015;9:529-34.

28. McDonnell G, Russell AD. Antiseptics and disinfectants: Activity, action, and resistance. Clin Microbiol Rev 1999;12:147-79.
29. Estrela C, Ribeiro RG, Estrela CR, Pécora JD, Sousa-Neto MD Antimicrobial effect of $2 \%$ sodium hypochlorite and $2 \%$ chlorhexidine tested by different methods. Braz Dent J 2003;14:58-62.

30. Okino LA, Siqueira EL, Santos M, Bombana AC, Figueiredo JA. Dissolution of pulp tissue by aqueous solution of chlorhexidine digluconate and chlorhexidine digluconate gel. Int Endod J 2004;37:38-41.

31. Weber CD, McClanahan SB, Miller GA, Diener-West M, Johnson JD. The effect of passive ultrasonic activation of $2 \%$ chlorhexidine or $5.25 \%$ sodium hypochlorite irrigant on residual antimicrobial activity in root canals. J Endod 2003;29:562-4.

32. Gomes BP, Ferraz CC, Vianna ME, Berber VB, Teixeira FB, Souza-Filho FJ, et al. In vitro antimicrobial activity of several concentrations of sodium hypochlorite and chlorhexidine gluconate in the elimination of Enterococcus faecalis. Int Endod J 2001;34:424-8.

33. Goztas Z, Onat H, Tosun G, Sener Y, Hadimli HH. Antimicrobial effect of ozonated water, sodium hypochlorite and chlorhexidine gluconate in primary molar root canals. Eur J Dent 2014;8:469-74.

34. Maniglia-Ferreira C, de Almeida Gomes F, Ximenes T, Neto MAT, Arruda TE, Ribamar GG, et al. Influence of reuse and cervical preflaring on the fracture strength of reciprocating instruments. Eur J Dent 2017;11:41-7. 